
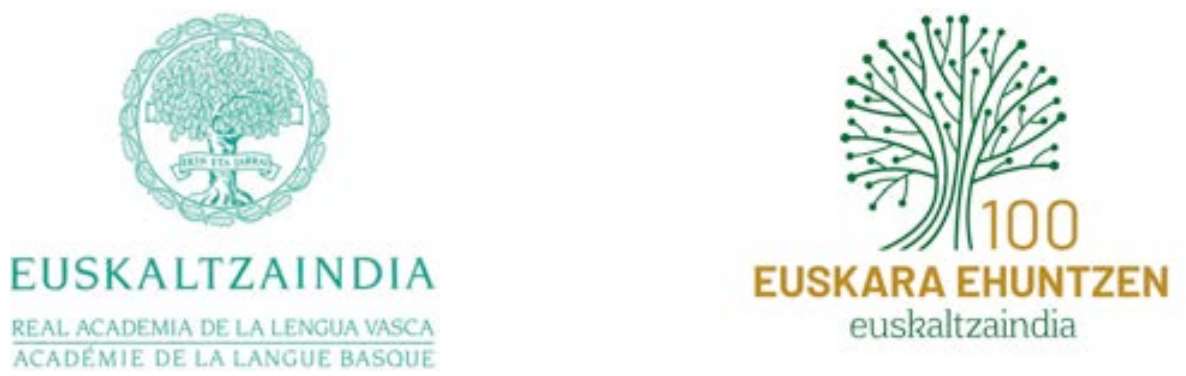

\title{
EUSKARA BATUAREN ADIERAZPENA
}

\section{Arantzazutik mundu zabalera}

Euskaltzaindiaren sorreratik ehun urte eta Arantzazuko Biltzarretik berrogeita hamar igaro direnean, Euskaltzaindiak honako adierazpen hau aurkeztu nahi dio euskal gizarteari, euskara batuaren inguruan eragile publiko zein pribatuek berresteko eta azpimarratzeko euskara batuaren garrantzia eta, horrekin batera, orain arteko ibilbidea eta etorkizuneko erronkak.

Hartara,

1.

Euskaltzaindiak berresten ditu bere sorrera bultzatu zuten printzipioak eta, aldi berean, euskara batuaren jatorrian daudenak. Euskaltzaindi sortu berri hura lehen ordutik hasi zen batasunaz arduratzen. Aurretik, idazleek ere euskaldunen arteko euskara bateratuaren beharra sumatua zuten eta nor bere neurrian eta moldean erantzuna ematen saiatua zen.

Euskaltzaindiaren sortarauetan ageri da jada euskararen batasuna "euskaldun guziak idatz-irakurketan erabiltzekoa". Ondoko ibilbidean zehar, auziaren inguruan egin diren saiakera, inkesta, proposamen, txosten edo ikerketak, eta an- 
tolatu diren biltzarrak, ez dira alferrikakoak izan, nahiz eta 1968ra arte ez zuten gailurra jo, alegia, Arantzazun euskara batasunaren bidean jarri eta handik hamar urtera Bergaran berretsi arte.

\section{2.}

Euskaltzaindia partaide izan da mendearen 50eko eta $60 \mathrm{ko}$ hamarkadetan euskalaritzan eta euskalgintzan nagusitzen ari ziren hizkuntza planteamendu berrietan. Belaunaldi berriek euskararen biziberritzea eta batasuna ezinbestekotzat joak zeuzkaten batasunaren bidez euskara gizarte berrira egokitzeko, irakaskuntzan, hedabideetan, kulturgintzan, eta, geroago, administrazioan. Arantzazun, Bilbon, Eibarren, Baionan, Ermuan eta beste leku askotan elkarrekin lanean aritzeko eskaintzak eta proposamenak egin ziren, eta haiek baliatzen jakin zuen Euskaltzaindiak Arantzazun, eta, ondoren, euskalgintzarekin eskuz esku egin zuen bidea eta halaxe eraman gidaritza, etenik eta pitzadurarik gabe.

3.

Euskaltzaindiak aho betean aitortzen du prozesu honetan parte hartu duten hainbaten lana, norbanako, talde edo erakunde izan, horiek ahalbidetu baitute, beren ekarpenekin, euskara batua moldatzea, aniztasunaren eta adostasunaren ikuspegitik.

Aitortu ez ezik, omenaldia ere egin nahi die bidegile horiei Euskaltzaindiak, eta baieztatzen du euskara batuak, euskaldun bakoitzaren errealitate linguistiko eta kultural berezietatik abiatuta, zin-zinezko elkargune emankorra ekarri duela, euskaraz, jatorriz zein ikasbidez, ari diren guztientzat.

Harro dago Euskaltzaindia horretaz, begien bistakoa baita Euskal Herriak eta herritarrek izan dutela ibilbide ausart eta oparo horretan protagonismorik erabatekoena. 
4.

Euskaltzaindiak omendu nahi ditu euskara batuaren gune hori hainbeste ilusio, lan eta nekeri esker osatu eta osotu duten guztiak. Hortxe dira, besteak beste, beraien buru euskalduna euskara batuaren bidez alfabetatu dutenak edota euskararen mundura ikasiaren bidez etorri diren hiztun berriak, abiaburu euskara batua duten euskaldunak, euskararen demografia berrian gero eta ugariago direnak, bestalde. Batzuek eta besteek euskara batua lanabes aproposa dute beren eguneroko zereginetan. Izan ere, euskara batua, lurraldean lurraldeko izateaz gainera, gizartearena ere bada, leku eta funtzio askotarikoa, hiztunen aho-mihietan eta idatzietan bizirik dagoena.

\section{5.}

Euskaltzaindiak dei egiten die belaunaldi berriei euskara batua, arrotza barik, bere-berea izan dezaten eta beraien adierazpideetan erabil dezaten, belaunaldi bakoitzak duen eite eta tankera propioarekin. Guztion artean bultzatu behar dugu euskara batua, gure arteko zubia izan dadin, nork berea duen euskaratik abiatuta, baina euskaldun guztion arteko estekadurak erabat bermaturik.

\section{6.}

Euskaltzaindia kezkaturik dago azkenaldian hizkuntza estandarrari buruz nabarmendu den zenbait iritzi eta jokamolderekin.

Euskaltzaindiak uste du euskaldun oso izateko modua ekarri digula euskara batuak: euskaldunon barne-lotura, hiztun guztiok errazago elkar ulertu ahal izateko zubi-tresna, euskaldun berrien eta zaharren arteko elkargune zabala, eta, azkenik baina ez azken, euskararen beraren izena eta omena. Begirunea zor zaio horri. 


\section{7.}

Euskaltzaindiak engaiamendua adierazten dio gizarteari, ez goitik beherako ezarpenaren aldetik, ezpada pedagogiaren eta konpromisoaren aldetik, ideologia politikoetatik at. Koordinazio lanaren bidez gauzatuko du euskara batuaren sustapena eta bultzada.

Koordinazio horretan ari dira Euskaltzaindia, euskalgintza, gizarte eragileak, herri-aginteak eta gainerako erakundeak, eta eginkizun horretan aintzat hartu behar dira euskara batuaren inguruko orain arteko erabakiak, euskara estandar baten nondik norakoak. Izatez, aurrerantzean ere eman beharko dira pausoak euskara batuaren alorrean euskalgintzarekin batera, hizkuntza zerbait bizia baita, etengabe aldatzen ari dena, gizarteak izan ditzakeen premiei egokitzeko asmotan. Hitz batez esateko, Euskaltzaindiak zerbitzua eman behar dio gizarteari, eta euskaldunengandik jasotzen duena euskaldunei itzuli, beraien onura eta erabilerarako.

\section{8.}

Euskara batuaren erabilera sozialari laguntza eman behar zaio, eta begien bistakoa da erabilera horri bidea erraztu behar zaiola, gaur egun gero eta zabalagoa baita euskara batuaren presentzia Euskal Herriko herrialde guztietan. Horretan ere, artez uztartu behar dira Euskaltzaindiaren betiko zereginak, alegia, euskara batuari buruzko formulazio linguistikoa eta sustatze lana, Akademiaren sortzaileek jarri zituzten Iker eta Jagon sailetan, hurrenez hurren. Historian zehar horren adibideak ugari dira Euskaltzaindiaren eginetan, eta garai hauetan ere hizkuntza politikaren eragile publiko zein pribatuekin ondu beharrekoak, eta horiekin batera jokatu behar du Euskaltzaindiak euskara batuaren aldeko hizkuntza politika sendoa egiten. 
9.

Zeregin horietan Euskaltzaindia bere jarduna eraberritzen ari da, gizarte moderno baten beharrei aurre egin ahal izateko, gizarte horrek euskaran berean bilatzen baitu, hizkuntza propioa duen aldetik, nortasun eta komunikazio tresna eragingarria eta egungo bizimoduari egokitua, hartarako baliagarria dena. Zeregin horietan badira berebiziko arloak euskara batuaren hedapenerako, hala nola irakaskuntza eta herriadministrazioa, euskara ofiziala izatearekin batera. Horiek guztiek ekarri diote euskarari egoera berria eta horien bitartez egin du bidea euskarak digitalizazio mundura, ezinbestekoa da-eta ingurune digitala Euskaltzaindiaren zereginetan, euskararen estandarizazioa eta erabilera soziala xede eta helmuga baititu euskararen Akademiak.

10.

Ehun urte joanak dira Euskaltzaindi sortu berriak, euskarararen bateratze-saioari ekin zionetik. Berrogeita hamar urte, berriz, Arantzazuko Biltzarra egin zenetik.

Euskara batuak, euskaldunen eginahalak tartean direla, eremu berriak irabazi ditu euskararentzat eta euskal kulturarentzat. Hala ere, oraindik badira irabazi beharrekoak.

Zeregin horretarako tresna paregabea dela erakutsi du euskara batuak, eta bere aitzinamenduan jarraitu behar dugu guztiok. Hurrengo berrogeita hamar urteetan ere bada motiborik, euskara batua indartzen saiatzeko: lanabes baliagarria da berau, aldian-aldian behar izan ditzakeen egokitzapenez hiztunen arteko hainbat jarduera errazteko eta bermatzeko: batez ere idatzizko jardunean eta mintzaera jaso-formalean erreferente argi eta noranahikoa eskuratzeko.

Hurrengo belaunaldien eskuetan jarri behar dugu ondare hori: etxetik eta lagunartetik euskaldun direnei beren hizkuntza-gaitasuna osatzeko eta aberasteko bidea emango 
diegu horrela, eta etxetik ez dakitenei euskaldun askoren esparrura erakartzeko aukera eskainiko. Belaunaldi berri horiei dagokie, eskuratu dieguna osatu, hobetu eta hurrengoei transmititzea. Horixe da bidea euskarari desio diogun etorkizuna bermatzeko. Zalantzarik gabe, bermatze horretan guztiok behar dugu partaide izan eta lehen-lehenik Euskaltzaindiak.

Arantzazun, 2018ko urriaren 6an 